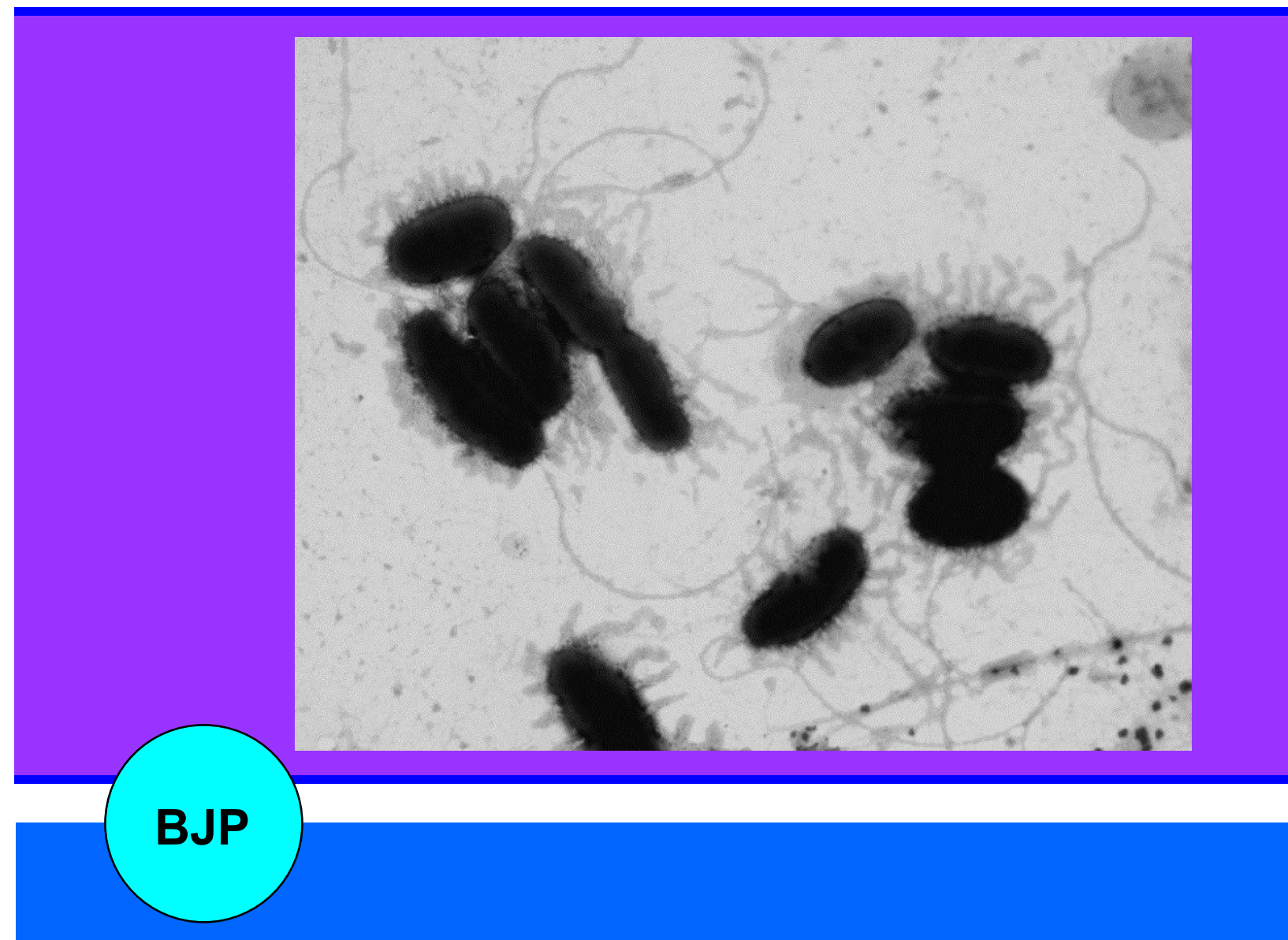

Bangladesh Journal of Pharmacology

Research Article

Isolation of a broad spectrum antibiotic producer bacterium, Pseudoalteromonas piscicida PG-02, from the Persian Gulf 
Abstracted/indexed in Academic Search Complete, Agroforestry Abstracts, Asia Journals Online, Bangladesh Journals Online, Biological Abstracts, BIOSIS Previews, CAB Abstracts, Current Abstracts, Directory of Open Access Journals, EMBASE/Excerpta Medica, Google Scholar, HINARI (WHO), International Pharmaceutical Abstracts, Open J-gate, Science Citation Index Expanded, SCOPUS and Social Sciences Citation Index

\title{
Isolation of a broad spectrum antibiotic producer bacterium, Pseudoalteromonas piscicida PG-02, from the Persian Gulf
}

\author{
Esmaeil Darabpour ${ }^{1}$, Mohammad Roayaei Ardakani ${ }^{1}$, Hossein Motamedi $^{1}$ and Mo- \\ hammad Taghi Ronagh ${ }^{2}$ \\ ${ }^{1}$ Department of Biology, Faculty of Science, Shahid Chamran University, Ahvaz, Iran; ${ }^{2}$ Department of Marine \\ Ecology, Marine Science \& Technology University, Khoramshahr, Iran.
}

\section{Article Info \\ Received: $\quad 13$ September 2011 \\ Accepted: $\quad 22$ September 2011 \\ Available Online: 25 October 2011 \\ DOI: 10.3329 / bjp.v6i2.8592}

Cite this article:

Darabpour E, Ardakani MR, Motamedi $\mathrm{H}$, Ronagh MT. Isolation of a broad spectrum antibiotic producer bacterium, Pseudoalteromonas piscicida PG02, from the Persian Gulf. Bangladesh J Pharmacol. 2011; 6: 74-83.

\begin{abstract}
The aim of this study was to isolation of marine antibiotic-producing bacteria from the Persian Gulf, as an untapped source for searching new natural drugs. Bioactivity of ethyl acetate extract prepared from marine bacterial isolates was evaluated against 21 human pathogenic bacteria. GCI (Growth Curve Interference) parameter was determined for the obtained marine antibiotic compound against MRSA (Methicillin resistant Staphylococcus aureus). Finally, identification of intended isolate was done based on phenotipically and phylogenetically characters. Overall, 49 bacterial colonies were isolated but only one isolate from coastal sediment identified as Pseudoalteromonas piscicida PG-02 showed antibacterial activity. It was effective against all of tested bacteria except Listeria monocytogenes (clinical), L. monocytogenes (ATCC 19112), Proteus mirabilis (clinical) and Klebsiella pneumoniae (clinical). GCI parameter was obtained with concentration just near to MIC (GCI: $20 \mathrm{mg} / \mathrm{mL}$ ). In conclusion, this marine bacterium can give hopes for treatment of diseases caused by multidrug resistant (MDR) bacteria.
\end{abstract}

\section{Introduction}

Antibiotic usually assumed as secondary metabolite with special chemical structure that produced during the idiophase of microbial growth (Das et al., 2006). Now-a-days, the rapid spread of multidrug-resistant (MDR) bacteria, re-emergent infections, and newly emerging infectious diseases have become a serious global public health threat which especially affects economic development. Furthermore, with respect to the spread of methicillin-resistant Staphylococcus aureus (MRSA), the most common causative agent of infections among hospitalized patients, development of new classes of antibiotic is urgently needed. So, in addition to engineered drugs using combinatorial chemistry strategies, search for new natural sources for drugs such as microbes from extreme ecological niches can be a good choice for pharmaceutical companies for antibiotic drug discovery.

Oceans as the largest ecosystem on earth with an enormous diversity of different life forms which cover $70 \%$ of the earth's surfaces represent a potential source for finding new bioactive compounds (Das et al., 2006). The sea is an immense and practically unexploited source of potentially useful biologically active substances. Marine bacteria are often under extreme conditions such as temperature, pressure, salinity and depletion of micro-nutrients, so, in order to survive and maintain their biological activities, bacteria must prompt some special metabolic pathways to produce biologically active compounds that in some cases these secondary metabolites might be structurally unique substances and serve as new pharmaceutical agents that not found in terrestrial sources (Carvalho and Fernandes, 2010; Oku et al., 2003). Today, several different antibiotics 
have been reported from marine bacteria which among them Streptomyces, Pseudoalteromoas, Alteromonas, Bacillus and Pseudomonas are most famous (Darabpour et al., 2010). The Persian Gulf is a relatively shallow and semienclosed body of water that has some special ecological conditions such as having high degree of temperature so that its average sea water temperature may rise to $35.8^{\circ} \mathrm{C}$ and due to high evaporation, its salinity can increased as high as $4 \%$ and so on (Agah et al., 2009). The objective of present work was to isolation of potent antibiotic producing bacteria from water and sediment samples collected from different stations of Persian Gulf, as an unexplored source for searching new natural drugs.

\section{Materials and Methods}

\section{Sample collection}

Different samples including coastal water, surface water, deep water, coastal sediment, bed sediment and mangrove forest sediment were collected from 21 study sites in some northern area of Persian Gulf, during February 2008 to November 2009 (Figure 1 and Table I). Water samples were harvested by strelized-niskin bottle (using 70\% ethanol prior to sampling) and subsequently samples were collected in sterilized glass bottles. Sediments were collected by sterilized van veen grab into sterilized plastic bags. All of the samples were kept at $4^{\circ} \mathrm{C}$ till to delivering to the laboratory.

\section{Isolation of bacteria from marine samples}

For isolation of marine bacteria from water samples, 8 $\mu \mathrm{L}$ from each sample was inoculated into Marine Agar 2216 (MA, Highmedia). Sediment samples were serially diluted using sterilized sea water $(1: 10 \mathrm{v} / \mathrm{v}$ ratio) and spread on the entire surface of marine agar 2216. Also, isolation of marine bacteria from both water and sediment samples was performed using pour plate technique. After incubation at $30^{\circ} \mathrm{C}$ for 3 days, developed colonies were purified by repeatedly subculturing on marine agar and finally, bacterial colonies with distinct characteristics such as pigmentation, size, opacity, elevation, margin and surface appearance (yeon et al., 2005) were chosen for further process.

\section{Production medium and preparation of extract}

For screening of the antibiotic producing bacteria, pure colonies were transferred to Erlenmeyer flasks containing Marine Broth (MB, Laboratorios CONDA) medium and were incubated at $30^{\circ} \mathrm{C}$ on a rotatory shaker $(140$ $\mathrm{rpm}$ ) to produce antibiotic compounds. After 2-5 days, the broth culture was centrifuged at $10,000 \mathrm{rpm}$ for 15 min at $4^{\circ} \mathrm{C}$, and then supernatant was extracted using same volume of ethyl acetate. Solvent was removed at $37^{\circ} \mathrm{C}$.

\section{Selected human pathogens}

A broad spectrum of human pathogenic bacteria including Standard (reference) and clinical isolates was selected for this study. Gram-positive bacterial species

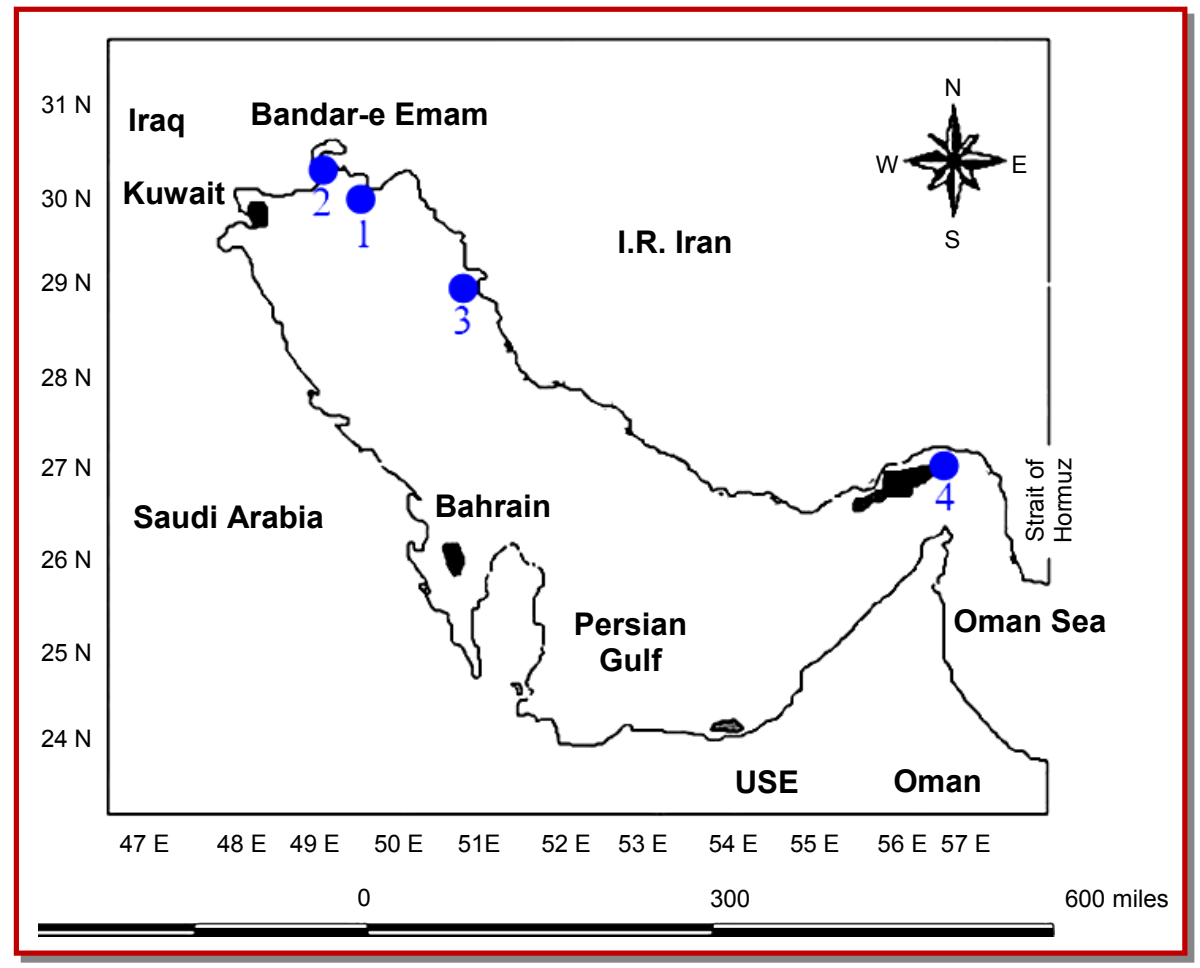

Figure 1: Map of sampling sites (1: Bahrakan port, 2: Mahshahr port, 3: Bushehr port, 4: Qeshm island) in the Persian Gulf 
were Staphylococcus aureus (ATCC 6538), Staphylococcus epidermidis (ATCC 12228), Bacillus subtilis (ATCC 12711), Listeria monocytogenes (ATCC 19112), MRSA (Methicillin Resistant Staphylococcus aureus) (clinical), Staphylococcus epidermidis (clinical), Bacillus anthracis (clinical), Bacillus cereus (clinical), Bacillus pumilus (clinical), L. Monocytogenes (clinical), and Streptococcus pyogenes (clinical). Gram negative bacterial species were Escherichia coli (ATCC 11303), Pseudomonas aeruginosa (ATCC 27853), Salmonella typhi (ATCC 19430), P. aeruginosa (clinical), E. coli (clinical), Proteus mirabilis (clinical), Brucella melitensis (clinical), S. typhi (clinical), Bordetella bronchiseptica (clinical) and Klebsiella pneumoniae (clinical). Standard strains were prepared from Iranian Research Organization for Science and Technology (IROST); and clinical species were originally isolated from clinical specimens and identified by standard biochemical reactions.

\section{Screening for antibacterial activity}

Freshly grown colonies of tested bacterial pathogens were used to inoculate Muller Hinton Broth (MHB, Merck) medium at $37^{\circ} \mathrm{C}$ for $5-8$ hours until turbidity of the suspension was adjusted to the Mc Farland 0.5 turbidity standard (108 cfu/mL) (Mulks et al., 1990; Asthana et al., 2009). Antibacterial activity was assessed two times by disc diffusion method. A total of $0.1 \mathrm{~mL}$ of bacterial suspension was poured on each plate containing Muller Hinton Agar (MHA, Merck). The lawn culture was prepared by sterile cotton swab and allowed to remain in contact for $1 \mathrm{~min}$. The dried crude extract was dissolved in ethyl acetate to a concentration of $50 \mathrm{mg} / \mathrm{mL}$. The sterile filter paper discs $(6 \mathrm{~mm}$ diameter) (Kanoh et al., 2008) were saturated by $35 \mu \mathrm{L}$ of this concentration of each extract and then were placed on lawn cultures. The Petri dishes were subse- quently incubated at $37^{\circ} \mathrm{C}$ for 24 hours and the inhibition zone around each disc was measured in $\mathrm{mm}$. Nine different antibiotics including vancomycin $30 \mu \mathrm{g}$, erythromycin $15 \mu \mathrm{g}$, methicillin $5 \mu \mathrm{g}$, carbenicillin $100 \mu \mathrm{g}$, nitrofurantoin $300 \mu \mathrm{g}$, penicillin $10 \mu \mathrm{g}$, oxacillin $1 \mu \mathrm{g}$, nafcillin $1 \mu \mathrm{g}$ and streptomycin $10 \mu \mathrm{g}$ were used as control. All these synthetic antibiotic discs were produced by Difco.

\section{MIC and MBC determination}

The MIC (Minimal Inhibitory Concentration) and MBC (Minimal Bactericidal Concentration) of ethyl acetate extract from the most effective bacterial strain were determined against two somewhat important and more sensitive bacteria. MIC was determined by the macro broth dilution assay method (Motamedi et al., 2010). In the tube dilution assay, standard bacterial suspension and different concentrations of extract $(5,10,20,40,80$, 160 , and $200 \mathrm{mg} / \mathrm{mL}$ ) were added to tubes containing 1 $\mathrm{mL}$ MHB medium. These tubes were incubated at $37^{\circ} \mathrm{C}$ for 24 hours. The first tube in the above series without sign of visible growth was considered as the MIC. MBC was determined by culturing one standard loop from tubes with no apparent growth on MHA and subsequent incubation at $37^{\circ} \mathrm{C}$ for 24 hours. The least concentration that inhibited colony formation on agar was considered as $\mathrm{MBC}$ for the extract.

\section{Kinetics of growth and antibiotic production}

Kinetic of growth and antibiotic production was studied in a batch culture system in a $250 \mathrm{~mL}$ Erlenmeyer containing $100 \mathrm{~mL}$ marine broth and at $30^{\circ} \mathrm{C}$ on a rotatory shaker (140 rpm). Kinetics of growth or biomass accumulation measured according to measuring of optical density (OD) at $600 \mathrm{~nm}$. At first, the best

Table I

The geographical characteristics and physicochemical properties of the major location of sampling sites in

\begin{tabular}{|ccccccc|}
\hline Temperature $\left({ }^{\circ} \mathrm{C}\right)$ & $\mathrm{pH}$ & Salinity $(\mathrm{g} / \mathrm{L})$ & Longitude & Latitude & Location Name & Station No. \\
\hline 16.9 & 7.2 & 40.0 & $49^{\circ} 34^{\prime}$ & $30^{\circ} 15^{\prime}$ & Bahrakan port & 1 \\
24.0 & 8.0 & 50.0 & $49^{\circ} 13^{\prime}$ & $30^{\circ} 33^{\prime}$ & Mahshahr port & 2 \\
30.7 & 8.1 & 43.5 & $50^{\circ} 51^{\prime}$ & $28^{\circ} 59^{\prime}$ & Bushehr port & 3 \\
30.0 & 8.4 & 39.5 & $55^{\circ} 23^{\prime}$ & $26^{\circ} 40^{\prime}$ & Qeshm Island & 4 \\
\hline
\end{tabular}

Table II

\begin{tabular}{|c|c|c|c|c|c|c|c|}
\hline \multicolumn{8}{|c|}{ Table II } \\
\hline \multicolumn{8}{|c|}{$\begin{array}{c}\text { Number of bacterial strains isolated from different samples collected from the northern regions of } \\
\text { Persian Gulf }\end{array}$} \\
\hline & $\begin{array}{c}\text { Coastal } \\
\text { water }\end{array}$ & $\begin{array}{c}\text { Surface } \\
\text { water }\end{array}$ & $\begin{array}{l}\text { Deep } \\
\text { water }\end{array}$ & $\begin{array}{l}\text { Coastal sedi- } \\
\text { ment }\end{array}$ & $\begin{array}{l}\text { Bed sedi- } \\
\text { ment }\end{array}$ & $\begin{array}{l}\text { Mangrove forest } \\
\text { sediment }\end{array}$ & Total \\
\hline Bahrakan port & - & 1 & 2 & 2 & 4 & - & 9 \\
\hline Mahshahr port & - & 2 & 3 & - & 3 & - & 8 \\
\hline Qeshm island & 2 & 1 & 3 & 4 & 1 & 2 & 13 \\
\hline Bushehr port & 2 & 2 & 4 & 4 & 7 & - & 19 \\
\hline
\end{tabular}


antibiotic producing bacterium was grown in marine broth. Serial samples were harvested from production medium at 2 hours intervals from 0 till 6 hours and 4 hours intervals from 6 hours till entering stationary and death phases of growth. Supernatants were harvested from these samples by centrifugation at $8,000 \mathrm{rpm}$ at $4^{\circ}$ $\mathrm{C}$ for $10 \mathrm{~min}$ and subsequently were sterilized by filtration $0.45 \mu \mathrm{m}$ and then used for antibacterial assay (Shibl and Sowaygh, 1980). Antibiotic activity of samples was assessed against MRSA using disc diffusion method.

\section{Determination of growth curve interference (GCI)}

GCI is a parameter which defined as the lowest concentration of an antibiotic compound that modifies the growth curve of tested pathogen compared with a control without antibiotic (Castillo et al., 2008). Tested pathogen in this study was MRSA. At first, four $250 \mathrm{~mL}$ flasks containing $15 \mathrm{~mL}$ MHB medium was prepared, and then freshly colonies of MRSA from a 24 hours culture on Nutrient Agar (NA, Merck) was inoculated in medium until turbidity of the suspension adjusted to the Mc Farland 0.5 turbidity standard. Also, $15 \mathrm{~mL}$ of crude extract from marine isolate at four concentrations equal to and below the MIC was prepared. A flask containing $30 \mathrm{~mL}$ MHB with the Mc Farland 0.5 turbidity of MRSA but without extract was used as control. Finally, each of the prepared extracts were added to one of the flasks and then incubated at $37^{\circ} \mathrm{C}$ on a rotatory shaker $(110 \mathrm{rpm})$; biomass accumulation measured (every 1 hour) according to measuring optical density (OD) at $600 \mathrm{~nm}$ until entering stationary and death phases of growth. Related curves were drawn and GCI was determined.

\section{Morphological and biochemical characterization of}

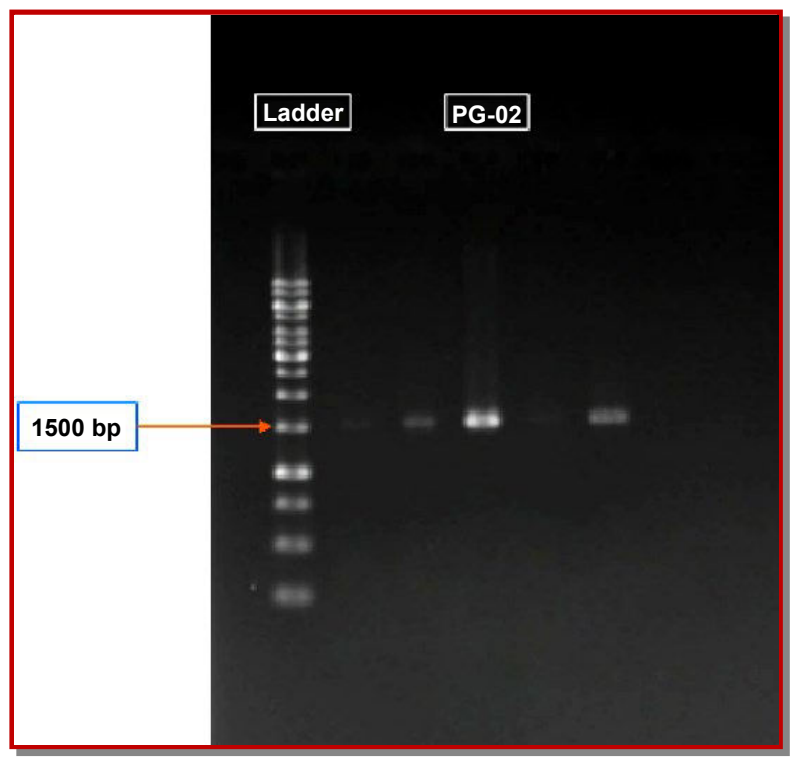

Figure 2: Agarose gel electrophoresis of amplified $16 \mathrm{~S}$ rRNA fragment (1500 bp) of PG-02 isolate

\section{antibiotic producer bacterium}

The isolated marine bacterial strain with antibacterial activity was identified based on morphological and biochemical characters according to the methods described in Bergey's manual for systematic of bacteriology (Garrity et al., 2006). Definite identification was done based on $16 \mathrm{~S}$ rRNA gene sequencing.

\section{Identification based on 16 S rRNA gene sequencing}

In order to genomic DNA extraction, a single colony of intended bacterium was sub-cultured in $\mathrm{MB}$ and incubated at $30^{\circ} \mathrm{C}$ for 48 hours. The genomic DNA was extracted by a commercial kit (Genfanavaran, Iran), according to the manufacture instruments. Full length sequence of $16 \mathrm{~S}$ rRNA genes was amplified from the isolated genomic DNA using the following universal bacterial $16 S$ rRNA primers: Forward strand: 5'CCGAATTCGTCGACAACAGAGTTTGATCCTGGCT CAG and reverse strand: CCCGGGATCCAAGCTTACGGTTACCTTGTTACGACTT-5' (Papizadeh et al., 2010). Polymerase chain reaction (PCR) was performed in a $50 \mu \mathrm{L}$ reaction mix (mixture) containing $50 \mathrm{mM}$ $\mathrm{MgCl}_{2}, 10 \mathrm{mM}$ each deoxynucleoside triphosphate (dATP, dTTP, dGTP and dCTP) dNTP, 10×PCR buffer, $10 \mathrm{pmol} / \mu \mathrm{L}$ of each primer, and $5 \mathrm{U}$ of Taq polymerase. The PCR thermal profile was consisted of denaturation at $94^{\circ} \mathrm{C}$ for $5 \mathrm{~min}$ followed by 30 cycles of amplification, each cycle consisting of a denaturation at $94^{\circ} \mathrm{C}$ for 1 min, annealing at $62^{\circ} \mathrm{C}$ for $40 \mathrm{sec}$, and chain elongation at $72^{\circ} \mathrm{C}$ for $2.5 \mathrm{~min}$. A final elongation step at $72^{\circ} \mathrm{C}$ for 20 min was included. The Electrophoresis of PCR product was done on $1 \%$ agarose gel for $55 \mathrm{~min}$ at $95 \mathrm{v} /$ $\mathrm{cm}$ in order to confirmation of the $16 \mathrm{~S}$ rRNA amplification (Figure 2). PCR product was sequenced by Genfanavaran biotech corp. Alignment of sequences was done by CLC Main Workbench 6.0 software program. The obtained sequences were compared to those available in the Genbank by BLAST searches (http://www.ncbi.gov/blast). Finally, phylogenetic tree was constructed by CLC Main Workbench 6.0 software program using the neighbor-joining algorithm (Saitou and Nei, 1987). Also, the obtained sequence from intended antibiotic producer bacterium was compared to the sequence of its closest phylogenetic neighbor strain by chimera check/pintail program (http://www.bioinformatics-toolkit.org/Web-Pintail/).

Morphological observation of antibiotic producer isolate

Surface morphology study of intended bacterium was done using scanning electron microscopy (SEM). A single colony of antibiotic producer bacterium from 24 hours culture on marine agar was dissolved in $5 \mathrm{~mL}$ sterile distilled-water and subsequently $2 \mu \mathrm{L}$ from this suspension was harvested and dried at room temperature. The prepared sample was coated by silver for $7 \mathrm{~min}$ and surface morphology was studied by Leo1455 
Vp scanning electron microscopy.

\section{Results}

In the present research we isolated a total of 49 bacterial strains from marine samples collected from Persian Gulf (Table II). The majority of isolates were obtained from sediment samples. Among all of isolates, only one bacterium from the coastal sediment collected from seashore of Bushehr port showed antagonistic activity against pathogenic bacteria and designated as PG-02. The prepared raw extract from broth culture of this bacterium was effective against most of the tested pathogens.

On the basis of obtained results from paper disc diffusion test (Table III), the antibiotic substance produced by indented marine bacterium has a broad-spectrum antibacterial activity as that among 21 tested bacterial pathogenic strains only L. monocytogenes (clinical), $L$. monocytogenes (ATCC 19112), P. mirabilis (clinical) and K. pneumoniae (clinical) showed reistance to the raw extract of PG-02 strain. Among Gram positive bacteria, S. aureus (ATCC 6538), S. epidermidis (ATCC 12228) and Str. pyogenes presented the most susceptibility to this antibiotic compound and about of Gram-negative bacteria, E. coli (ATCC 11303), S. typhi (ATCC 19430) and B. bronchiseptica (clinical) were the most susceptible strains. Also, tested Bacillus species exhibited a good level of sensitivity to antibiotic produced by PG-02. All of the examined clinical bacteria were multidrug resistant (MDR). Clinical S.aureus strain was resistant to methicillin so named MRSA. Antibacterial activity of the raw extract of PG-02 against MRSA in comparsion to synthetic antibiotics was remarkble. $P$. aeruginosa (clinical) and E. coli (clinical) were the most resistant strains to synthetic antibiotics while the growth inhibition effect of intented natural antibiotic was considerable. Among tested bacteria, only S. aureus (ATCC 6538) and B. subtilis (ATCC 12711) were sensitive to penicllin. On the other hand, all of tested pathogens were resistant to oxacillin.

MIC and MBC values for ethyl acetate extract of PG-02 broth culture against MRSA were 40 and $70 \mathrm{mg} / \mathrm{mL}$, respectively. Meanwhile, MIC and MBC values against B. bronchiseptica were the same $(15 \mathrm{mg} / \mathrm{mL})$.

On the basis of obtained results from growth curve of PG-02 and disc diffusion test (Figure 3), production of antibiotic by PG-02 was occurred after about 64 hours of growth when the culture entered in the late stationary phase and extended to death phase and

Table III

Antibacterial activity of ethyl acetate extract of Pseudoalteromonas piscicida PG-02 against some clinical and standard pathogens compared with commercial antibiotics

\begin{tabular}{|c|c|c|c|c|c|c|c|c|c|c|}
\hline \multirow{2}{*}{ Bacterial species } & \multirow{2}{*}{$\begin{array}{l}\text { Concentration of } \\
\text { extract }(\mathrm{mg} / \mathrm{mL})\end{array}$} & \multicolumn{9}{|c|}{ Antibiotic disc } \\
\hline & & VA & CB & $\mathrm{P}$ & FM & MT & $\mathrm{S}$ & NF & $\mathrm{E}$ & OX \\
\hline \multicolumn{11}{|l|}{ Gram-positive bacteria } \\
\hline B.pumilus & 16 & 15 & 13 & $\mathrm{R}$ & 17 & 22 & 16 & $\mathrm{R}$ & 15 & $\mathrm{R}$ \\
\hline B. anthracis & 15 & 20 & 16 & $\mathrm{R}$ & 21 & 23 & 14 & $\mathrm{R}$ & 21 & $\mathrm{R}$ \\
\hline B. cereus & 14 & 19 & 15 & $\mathrm{R}$ & 18 & 23 & 15 & $\mathrm{R}$ & 15 & $\mathrm{R}$ \\
\hline S. aureus & 16 & 22 & 31 & $\mathrm{R}$ & 23 & $\mathrm{R}$ & 12 & $\mathrm{R}$ & 16 & $\mathrm{R}$ \\
\hline S. epidermidis & 15 & 25 & 18 & $\mathrm{R}$ & 22 & 13 & 13 & $\mathrm{R}$ & 14 & $\mathrm{R}$ \\
\hline Str. pyogenes & 20 & 30 & 18 & $\mathrm{R}$ & 26 & 23 & 18 & $\mathrm{R}$ & 25 & $\mathrm{R}$ \\
\hline L. monocytogenes & $\mathrm{R}$ & 17 & 12 & $\mathrm{R}$ & 16 & $\mathrm{R}$ & 15 & $\mathrm{R}$ & 16 & $\mathrm{R}$ \\
\hline S. aureus ATCC & 19 & 18 & 26 & 12 & 23 & 13 & 16 & 10 & 28 & $\mathrm{R}$ \\
\hline S. epidermidis ATCC & 18 & 15 & 31 & $\mathrm{R}$ & 28 & 15 & 18 & $\mathrm{R}$ & 30 & $\mathrm{R}$ \\
\hline B. subtilis ATCC & 16 & 24 & 19 & 13 & 23 & 18 & 21 & 13 & 23 & $\mathrm{R}$ \\
\hline L. monocytogenes ATCC & $\mathrm{R}$ & $\mathrm{R}$ & 16 & $\mathrm{R}$ & 14 & 11 & 18 & 12 & 19 & $\mathrm{R}$ \\
\hline \multicolumn{11}{|l|}{ Gram-negative bacteria } \\
\hline E. coli & 15 & $\mathrm{R}$ & 22 & $\mathrm{R}$ & 20 & $\mathrm{R}$ & $\mathrm{R}$ & $\mathrm{R}$ & $\mathrm{R}$ & $\mathrm{R}$ \\
\hline S. typhi & 13 & $\mathrm{R}$ & 28 & $\mathrm{R}$ & 21 & $\mathrm{R}$ & $\mathrm{R}$ & $\mathrm{R}$ & $\mathrm{R}$ & $\mathrm{R}$ \\
\hline P. mirabilis & $\mathrm{R}$ & 24 & 28 & $\mathrm{R}$ & 10 & 14 & $\mathrm{R}$ & $\mathrm{R}$ & $\mathrm{R}$ & $\mathrm{R}$ \\
\hline B. bronchiseptica & 21 & $\mathrm{R}$ & 13 & $\mathrm{R}$ & 17 & 30 & 18 & $\mathrm{R}$ & 17 & $\mathrm{R}$ \\
\hline K. pneumoiae & $\mathrm{R}$ & 13 & 26 & $\mathrm{R}$ & 18 & $\mathrm{R}$ & $\mathrm{R}$ & $\mathrm{R}$ & $\mathrm{R}$ & $\mathrm{R}$ \\
\hline P. aeruginosa & 13 & $\mathrm{R}$ & 19 & $\mathrm{R}$ & $\mathrm{R}$ & $\mathrm{R}$ & $\mathrm{R}$ & $\mathrm{R}$ & $\mathrm{R}$ & $\mathrm{R}$ \\
\hline B. melitensis & 15 & $\mathrm{R}$ & 27 & $\mathrm{R}$ & 28 & $\mathrm{R}$ & 11 & $\mathrm{R}$ & $\mathrm{R}$ & $\mathrm{R}$ \\
\hline E. coli ATCC & 22 & 18 & 31 & $\mathrm{R}$ & $\mathrm{R}$ & $\mathrm{R}$ & 18 & $\mathrm{R}$ & 20 & $\mathrm{R}$ \\
\hline P. aeruginosa ATCC & 15 & $\mathrm{R}$ & 25 & $\mathrm{R}$ & $\mathrm{R}$ & $\mathrm{R}$ & $\mathrm{R}$ & $\mathrm{R}$ & 14 & $\mathrm{R}$ \\
\hline S. typhi ATCC & 16 & 10 & 32 & $\mathrm{R}$ & 20 & $\mathrm{R}$ & 10 & $\mathrm{R}$ & $\mathrm{R}$ & $\mathrm{R}$ \\
\hline
\end{tabular}




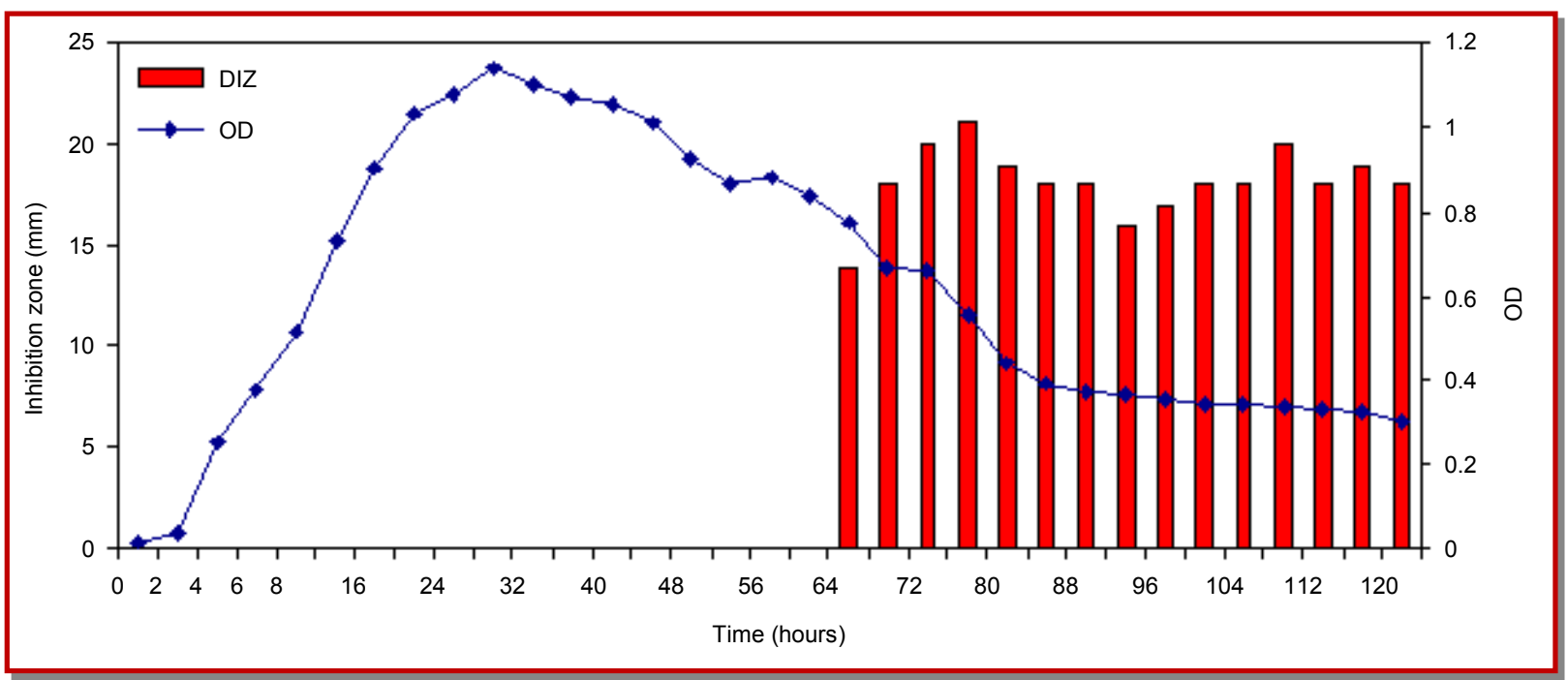

Figure 3: Results of Co-variation between cell growth of Pseudoalteromonas piscicida PG-02 and its antibiotic production

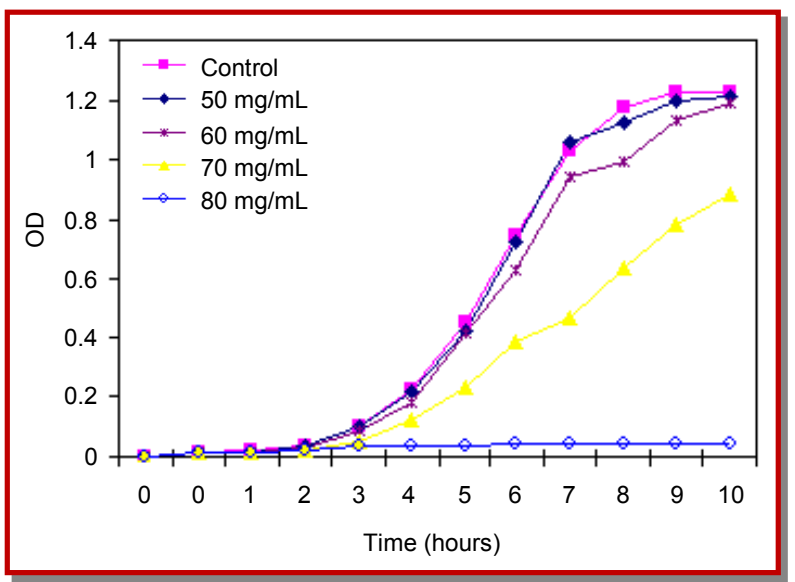

Figure 4: Determination of GCI parameter for Pseudoalteromonas piscicida PG-02 broth culture extract against MRSA

remained stable with minor fluctuations in the antibacterial activity. This means that intended antibiotic is produced mainly during the period of growth cessation. The maximum antibiotic effect against MRSA was observed from the sample harvested at 76 hours age culture.

Figure 4 revealed that GCI parameter for antibiotic component produced by PG-02 against MRSA was obtained with concentration immediately blow MIC (70 $\mathrm{mg} / \mathrm{mL}$ ) so that at this concentration, growth curve of MRSA after 10 hours was not reached to stationary phase compared with control. Nonetheless, also growth curve of MRSA was affected partially at 60 and $50 \mathrm{mg}$ / $\mathrm{mL}$ compared to control.

The obtained results from biochemical diagnostic tests (Table IV) presented that antibiotic producer isolate is a Gram negative rod (Figure 5), motile, aerobe and with oxidative metabolism that utilizes D-glucose and maltose as carbon source. PG-02 isolate was capable to growth at $\mathrm{NaCl} 8 \%$. Therefore, it was assumed as a moderately-halophilic bacterium. On the basis of BLASTn search of Genbank, the isolate PG-02 showed the most similarity to Pseudoalteromonas piscicida strain 1314 (nucleotide identity: 98\%) so it was finally identified as Pseudoalteromonas piscicida PG-02. The phylogenetic tree shows a relatively wide phylogenetic heterogeneity of Pseudoalteromonas piscicida PG-02 with other Pseudoalteromonas species (Figure 6). Also, the mean of the observed \%differences between Pseudoalteromonas piscicida PG-02 and 1314 (Figure 7) was 0.20 , and is roughly equivalent to evolutionary distance. The Genbank accession number for the $16 \mathrm{~S}$ rRNA gene sequence of strain PG-02 is JF509137.

\section{Discussion}

Antibiotic resistance among pathogenic bacteria is usually of greater magnitude in developing countries that is very important in national and international economical, political and scientific aspects. For instance, MRSA particularly is responsible for the largest outbreak of hospital-acquired infection (HAI) that the world has ever seen, so there is a continued need to develop new antibiotics. Unfortunately, because of the ability of bacteria in exchanging of genetic information and new mutations this problem has been more complicated (Tenover, 2006). With respect to enormous biodiversity in the marine environment so that in the case of microorganisms, sea water is composed of 78 million microscopic cell per ounce or the bottom, which mimic the soil, contain more than 1 billion cells in the volume of an ordinary cube of sugar this environment as a rich resource can be exploited for developing new natural pharmaceutical products especially antibiotics (Darabpour et al., 2010). Furthermore, existence of a 
given the intense microbial competition for resources such as space and nutrients between marine bacteria especially those that inhabited in sediment introduce a powerful selection pressure that can cause excretion of metabolites by these microorganisms for help mediate microbe-microbe interaction that occur on the order of micrometers, it is likely that many of these metabolites were structurally unique and bioactive secondary metabolites (Teasdale et al., 2009; Balcazar et al., 2010). Rosnfeld and Zobell, in 1947, were reported the first document of antibiotic producing marine bacterium (McCarthy et al., 1994). In this study, of 49 marine isolates only one bacterium that was isolated from sediment showed antibacterial activity; so, this result can confirm the hypothesis mentioned above about antibiotic producer marine bacteria that imply on particle-inhabited bacteria had broader-spectrum ability in antibiotic production than free-live bacteria (Long et al., 2001). This isolate is a Gram negative that belongs to $\gamma$-proteobacteria phylum, various studies have been shown that Gram negative bacteria (most abundant bacteria in the marine environment) especially those that belong to $\gamma$-proteobacteria have a particular potential for antibiotic production (Long et al., 2003; Shankar et al., 2010). The antibiotic compound produced by PG02 presented a very good level of antibacterial activity against tested human pathogenic bacteria including both Gram positive and negative bacteria so that it was effective against $81 \%$ of tested bacteria (Table III). Three of the most important tested clinical pathogens including S. aureus (clinical), E. coli (clinical) and P. Aeruginosa (clinical) showed a high level of resistance to synthetic antibiotics while antibacterial effect of intended antibiotic compound was considerable compared to these antimicrobials.

MRSA as major nosocomial pathogen exhibited resistance to $50 \%$ of tested synthetic antibiotics. Also, L. monocytogenes (ATCC and clinical strains) which is responsible for Listeriosis (sever food-borne illness) was resistant to intended natural antibiotic and more of the synthetic antibiotics, so this strain must be focused with

\section{Table IV}

\section{Morphological and Biochemical characteristics of Pseudoalteromonas piscicida PG-02}

\begin{tabular}{|lccc|}
\hline Parameter & Character & Parameter & Character \\
\hline Cell shape & Rod & Growth at $4^{\circ} \mathrm{C}$ & - \\
Pigmentation & Orange & Growth at $42^{\circ} \mathrm{C}$ & - \\
Gram reaction & Negative & Growth at $8 \% \mathrm{NaCl}$ & + \\
Catalase & + & O-F test & + \\
Oxidase & + & Acid from: & + \\
Motility & + & D-glucose & - \\
Indol production & - & L-arabinose & - \\
Citrate utilization & + & D-mannitol & + \\
Urease & - & Maltose & - \\
Nitrate reduction & + & Xylose & - \\
Gelatin hydrolysis & - & Sensitivity to : & - \\
TSI & Alk/Alk & Penicillin & - \\
\hline
\end{tabular}

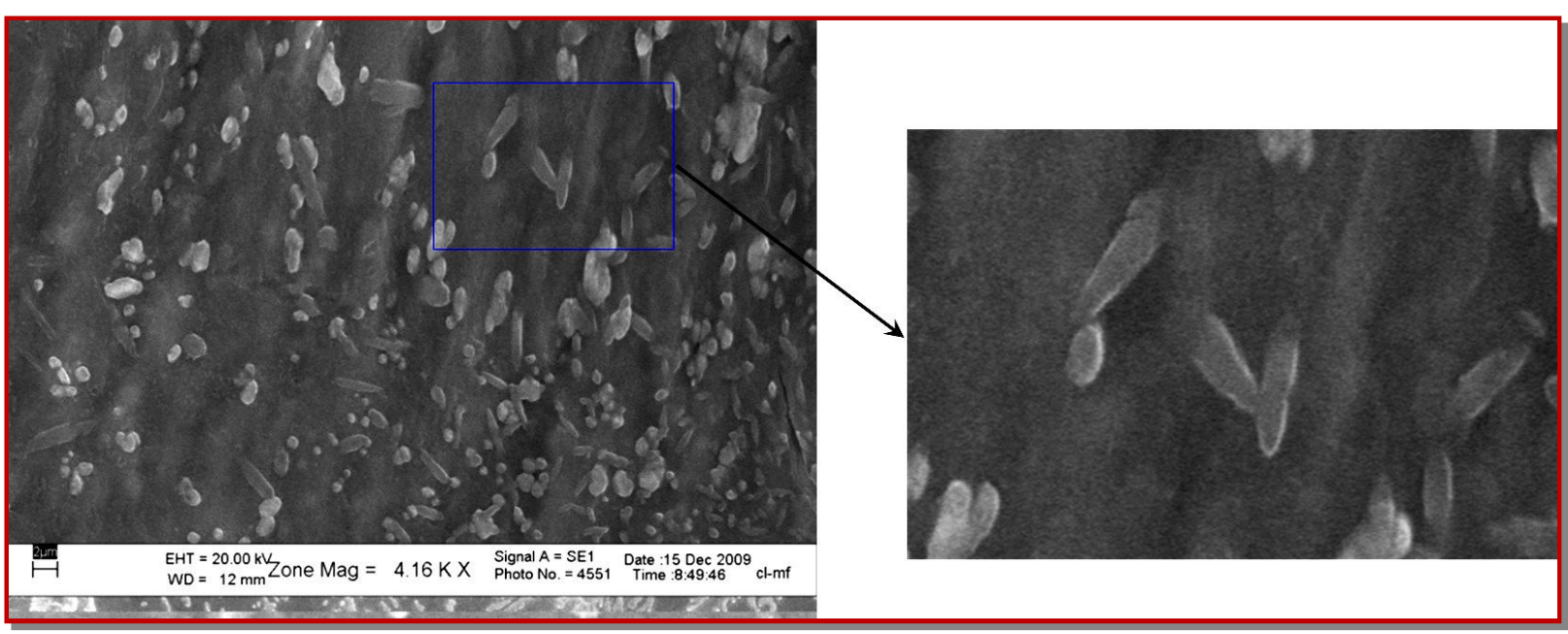

Figure 5: Scanning Electronic Microscope micrographs of PG-02 isolate in order to study of its morphology 


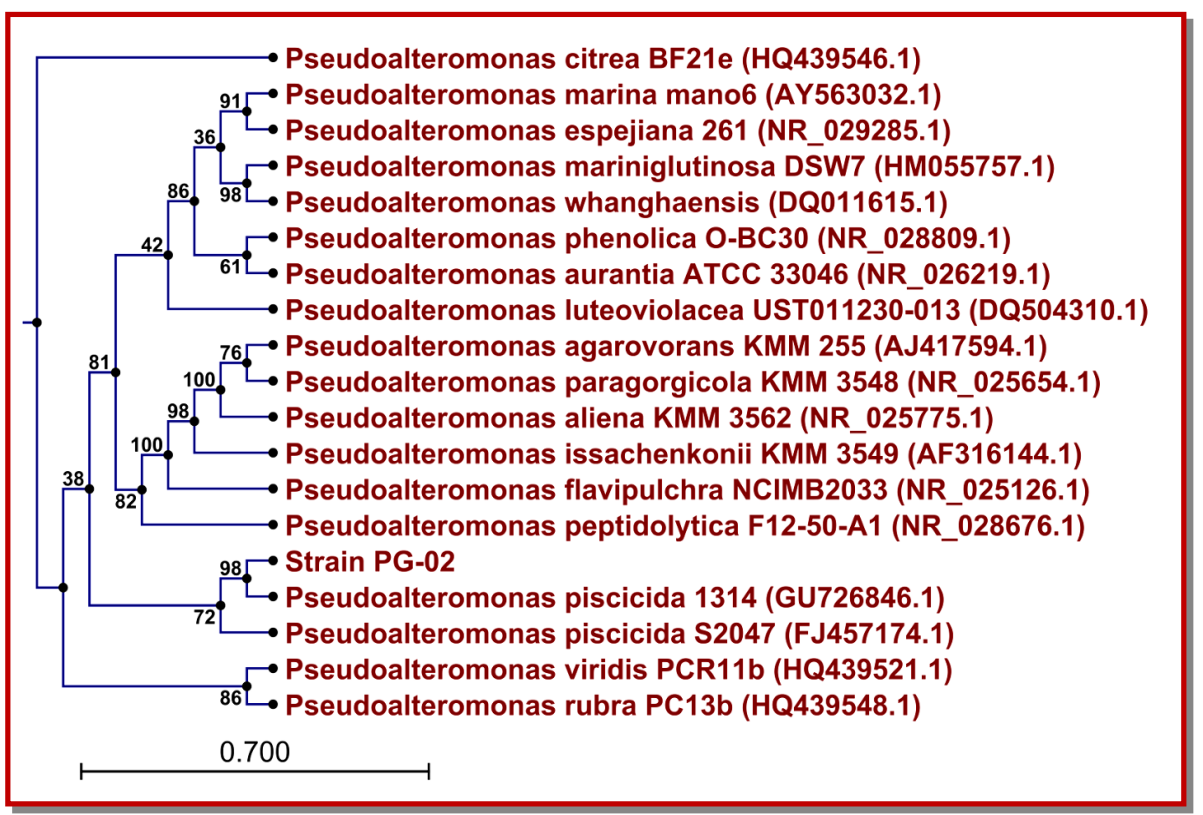

Figure 6: Phylogenetic relationships of Strain PG-02 and some related Pseudoalteromonas species on the basis of 16S rRNA gene sequence analysis. Numbers at branch nodes are bootstrap values (expressed as a percentage of 1000 replicates) based on the neighbour-joining algorithm. Bar represents approximately $0.7 \%$ nucleotide sequence difference

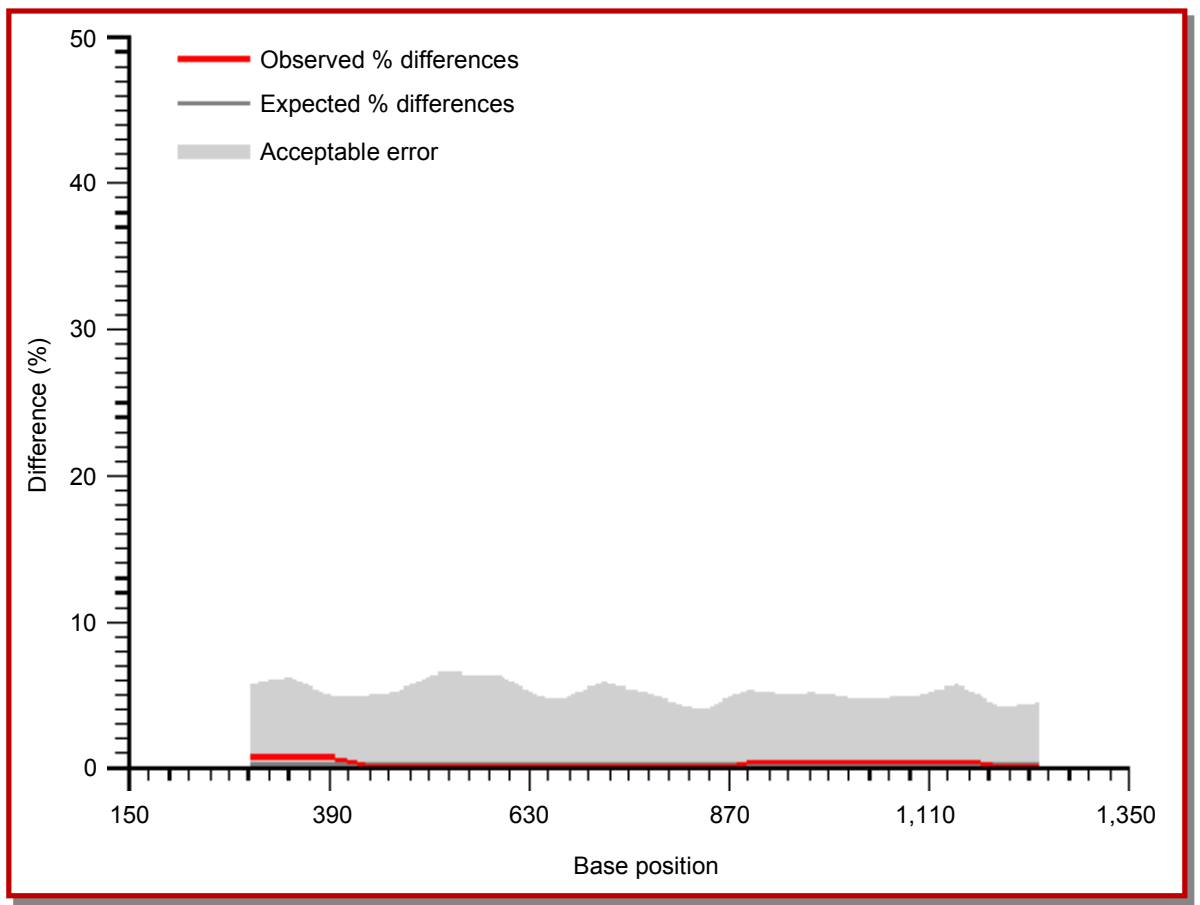

Figure 7: Variation in \% difference between P. piscicida 1314 (1372 nt) and P. piscicida PG-02 (1248 nt) determined with a 300 base sliding window, moving 25 bases at a time along the sequences' length

respect to its high level of resistance. Also, antistaphylococcal and anti-bacillus activity of the antibiotic produced by Pseudoalteromonas piscicida PG-02 was valuable. All of tested bacteria were resistant to oxacillin, so it seems that gradually we should exit this antibiotic from the usual antibiotic list. MIC and MBC values for ethyl acetate extract of $P$. piscicida PG-02 broth culture against B. bronchiseptica were same, so antibiotic compound existed in extract can act as bactericidal agent against this pathogenic bacterium (Motamedi et al., 2010). Because of urgently need for developing new antibacterial agents against MRSA; we have focused on antibacterial activity of the intended antibiotic against this rebellious pathogenic bacterium. 
Results of kinetic of growth and antibiotic production for P. piscicida PG-02 (Figure 3) revealed that production of antibiotic against MRSA was begun in the middle stages of stationary phase and extended in death phase; so it can be concluded that this antibiotic as a secondary metabolite will be produced during secondary metabolism and also production of antibiotic will be occurred parallel to the biomass accumulation; that is to say, kinetic of antibiotic production by $P$. piscicida PG-02 is growth-associated (Isnansetyo et al., 2009).

Based on the obtained results from GCI parameter (Figure 4), antibacterial activity of indented antibiotic compound against MRSA was maintained with subMIC concentration, this outcome has a pharmaceutical importance especially for high-risk patients. At first, the morphological characters and biochemical tests of PG02 indicate that this strain might be one member of Pseudomonas genus but based on homology obtained from 16S rRNA, this strain belongs to Pseudoalteromonas genus and piscicida species; however, because $98 \%$ sequence similarity (is not $100 \%$ ) and some particular biochemical and morphological characters (compared to those that mentioned in Bergey's manual of systematic bacteriology; Garrity et al., 2006) such as inability to use of ammonia but ability to nitrate reduction, this strain can be considered as a novel species in the genus Pseudoalteromonas and this hypothesis must be confirmed by further phenotypic characterization and DNA-DNA hybridization.

\section{Conclusion}

The antibacterial compound produced by Pseudoalteromonas piscicida PG-02 is a broad spectrum antibiotic that has a good level of inhibitory effect against most of the human pathogenic bacteria especially MDR bacteria such as MRSA, E. coli and P. aeruginosa. Considering MIC, MBC and GCI parameters, this marine antibiotic can be used as an anti-MRSA compound with high efficiency.

\section{Acknowledgments}

The authors wish to thank the vice chancellor for research of Shahid Chamran University, Ahvaz, Iran, for the research grant and financial support.

\section{References}

Agah H, Elskens M, Fatemi SMR, Owfi F, Baeyens W, Leermakers M. Mercury speciation in the Persian Gulf sediments. Environ Monit Assess. 2009; 157: 363-73.

Asthana RK, Deepali, Tripathi MK, Srivastava A, Singh AP,
Singh SP, Nath G, Srivastava R, Srivastava BS. Isolation and identification of a new antibacterial entity from the Antarctic Cyanobacterium Nostoc CCC 537. J Appl Phycol. 2009; 21: 81-88.

Balcazar JL, Loureiro S, Silva YJD, Pintado J, Planas M. Identification and characterization of bacteria with antibacterial activities isolated from seahorses (Hippocampus guttulatus). J Antibiot. 2010; 63: 271-74.

Carvalho CCR, Fernandes P. Production of metabolites as bacterial responses to the marine environment. Mar Drugs. 2010; 8: 705-27.

Castillo A, Liebana J, Lopez E, Baca P, Liebana JM., Liebana MJ, Castillo F. Interference of antibiotics in the growth curves of oral Streptococci. Int J Antimicrob Agents. 2006; 27: 263-66.

Darabpour E, Ardakani MR, Motamedi H, Ghezelbash G, Ronagh MT. Isolation of an antibiotic producer Pseudomonas sp. from the Persian Gulf. Asian Pac J Trop Med. 2010; 3: 318 $-21$.

Das S, Lyla PS, Khan SA. Marine microbial diversity and ecology: Importance and future perspectives. Curr Sci. 2006; 90: 1325-35.

Garrity GM, Bell JA, Lilburn TI. Pseudoalteromonas. In: Bergey's manual of systematic bacteriology. Bownan JP, McMeekin TA (eds). 2nd ed. New York, Springer, 2006, pp 467-77.

Isnansetyo A, Istiqomah I, Muhtadi, Sinansari S, Hernawan RK, Widada J. A potential bacterial biocontrol agent, strain S2V2 against pathogenic marine Vibrio in aquaculture. World J Microbiol Biotechnol. 2009; 25: 1103-13.

Kanoh K, Adachi K, Katsuta A, Shizuri Y. Structural determination and proposed biosynthesis of Alcanivorone, a novel a -pyrone produced by Alcanivorax jadensis. J Antibiot. 2008; 61: 70-74.

Long RA, Azam F. Antagonistic interactions among marine pelagic bacteria. Appl Environ Microbiol. 2001; 67: 4975-83.

Long RA, Qureshi A, Faulkner DJ, Azam F. 2-n-Pentyl-4-quinolinol produced by a marine Alteromonas sp. and its potential ecological and biogeochemical Roles. Appl Environ Microbiol. 2003; 69: 568-76.

McCarthy SA, Johnson RM, Kakimoto D. Characterization of an antibiotic produced by Alteromonas luteoviolacea Gauthier 1982, 85 isolated from Kinko Bay, Japan. J Appl Bacteriol. 1994; 77: 426-32.

Motamedi H, Darabpour E, Gholipour M, Seyyed Nejad SM. In vitro assay for the anti-brucella activity of medicinal plants against tetracycline-resistant $\mathrm{Br}$. melitensis. J Zhejiang UnivSci B (Biomed \& Biotechnol). 2010; 11: 506-11.

Mulks MH, Nair MG, Putnam AR. In vitro antibacterial activity of Faeriefungin, a new broad-spectrum polyene macrolide antibiotic. Antimicrob Agents Chemother. 1990; 34: 1762-65.

Oku N, Kawabata K, Adachi K, Katsuta A, Shizuri Y. Unnarmicins $\mathrm{A}$ and $\mathrm{C}$, new antibacterial depsipeptides produced by marine bacterium Photobacterium sp. MBIC06485. J Antibiot. 2008; 61: 11-17.

Papizadeh M, Roayaei Ardakani M, Ebrahimipour G, 
Motamedi H. Utilization of dibenzothiophene as sulfur source by Microbacterium sp. NISOC-06. World J Microbiol Biotechnol. 2010; 26: 1195-1200.

Saitou N, Nei M. The neighbor-joining method: A new method for reconstructing phylogenetic trees. Mol Biol Evol. 1987; 4: 406-25.

Shankar CVS, Malar AHJ, Punitha SMJ. Antimicrobial activity of marine bacteria associated with Polychaetes. Biores Bull. 2010; 1: 24-28.

Shibl AM, Sowaygh AL. Antibiotic inhibition of protease production by Pseudomonas aeruginosa. J Med Microbiol. 1980; 13: 345-49.
Talaro KP. Foundations in microbiology. 7th ed. New York, McGraw Hill, 2009.

Teasdale ME, Liu J, Wallace J, Akhlaghi F, Rowley DC. Secondary metabolites produced by the marine bacterium Halobacillus salinus that inhibit Quorum sensing-controlled phenotypes in gram-negative bacteria. Appl Environ Microbiol. 2009; 75: 567-72.

Tenover FC. Mechanisms of antimicrobial resistance in bacteria. Am J Med. 2006; 119: S3-S10.

Yeon SH, Jeong WJ, Park JS. The diversity of culturable organotrophic bacteria from local solar salterns. J Microbiol. 2005; 43: 1-10. 